\title{
RAGAM KULINER SESAJI DALAM UPACARA TRADISI DI KABUPATEN JEPARA
}

\author{
Sri Indrahti, ${ }^{*}$ Siti Maziyah, Alamsyah \\ Departemen Sejarah Fakultas Ilmu Budaya \\ Universitas Diponegoro
}

Alamat korespondensi:indrahti@gmail.com

Diterima/ Received: 15 Januari 2017; Disetujui/ Accepted: 24 Februari 2017

\begin{abstract}
This article is one of wide studies that analyze culinary food served in cultural activities at Jepara. Those cultural activities become tourist attractions. This study uses qualitative method includes collection of primary and secondary sources such as literature study, observation, structured and in-depth interviews, and Focus Group Discussion (FGD). Historically, cultural activities have been existed during the ancestor period, it is always accompanied by the presence of culinary that has philosophical and historical significance among them. The purpose of this study is to develop culinary culture into business units for the community by combining cultural and tourism market values that have been existed previously. The culinary varieties are expected to be able to contribute in tourism development through the establishment of new business units.
\end{abstract}

Keywords: Cultural activities; Culinary; Jepara

\begin{abstract}
Abstrak
Artikel ini mengangkat topik tentang ragam kuliner sesaji dalam upacara tradisi, merupakan salah satu kajian tentang berbagai macam kuliner yang disajikan dalam kegiatan budaya yang terdapat di Jepara. Aktivitas budaya tersebut menjadi destinasi wisata yang menarik bagi para wisatawan. Penelitian ini menggunakan metode kualitatif yang meliputi pengumpulan sumber primer dan sekunder seperti studi pustaka, observasi, wawancara terstruktur, in-depth interview, dan Focus Group Discussion (FGD). Secara historis, aktivitas budaya yang telah eksis selalu disertai dengan keberadaan kuliner yang mempunyai makna filosofis dan historis. Adapun tujuan penelitian ini adalah mengembangkan budaya kuliner yang ada menjadi unit-unit usaha baru bagi masyarakat dengan memadukan antara nilai budaya serta nilai pemasaran wisata yang sudah ada sebelumnya. Dengan demikian diharapkan ragam kuliner mampu memberikan kontribusi pengembangan wisata melalui upaya memunculkan unit-unit usaha baru.
\end{abstract}

Kata Kunci: Upacara tradisi; Kuliner; Jepara

\section{PENDAHULUAN}

Kebudayaan merupakan akumulasi proses interaksi yang lama antara manusia dengan lingkungan alam dan lingkungan sosialnya, sehingga menjadi identitas suatu bangsa
(Soekmono, 1993; Koentjaraningrat, 1990). Di Jepara terdapat berbagai macam sumber daya budaya (cultural resources) yang dapat dipandang sebagai rekaman sejarah (Garraghan, 1956:11; Maziyah, dkk., 2006; Hayati, dkk., 2007). Sumber daya budaya yang bersifat fisik 
(tangible) (Alamsyah dan Siti Maziyah, 2008) dan nonfisik (intangible) (Indrahti, dkk., 2012) merupakan kekayaan yang tidak ternilai dan sekaligus sebagai identitas budaya atau kepribadian budaya lokal, yang pada gilirannya dapat mewujudkan sikap mantap dalam memper-tahankan dan memupuk karakter bangsa sehingga bangsa Indonesia mampu eksis dalam era pengaruh global tanpa perlu kehilangan identitas kepribadian bangsanya (Atmosudiro, 2004:2).

Warisan budaya tak benda (WBTB) di Jepara salah satunya adalah keahlian memasak. Pengetahuan lokal ini dapat menjadi ikon atau identitas lokal Jepara, dan jika dikembangkan akan dapat meningkatkan ekonomi masyarakat pendukung. Kuliner sangat bermanfaat sebagai salah satu penopang ekonomi masyarakat. Melalui kuliner ini, masyarakat secara mandiri mampu menghidupi diri dan keluarganya sekaligus menggerakkan ekonomi lokal. Setiap makanan memiliki kearifan lokal dan kontribusi positif terhadap masyarakat setempat.

Sebetulnya kuliner adalah salah satu sarana komunikasi masyarakat dalam upacara tradisi yang sedang mereka selenggarakan kepada kekuatan tertinggi yang telah memberi kehidupan (Allah SWT) sebagai pusat harapan berbagai keinginan positif masyarakat (Sholikhin, 2010:49). Seiring dengan berjalannya waktu, makna berbagai jenis kuliner pelengkap upacara sebagai sarana komunikasi itu semakin tidak difahami oleh masyarakat pemilik tradisi.

Kedatangan agama Hindu dan Buddha pada sekitar abad ke-5 telah mewarnai kepercayaan masyarakat Jawa. Keberadaan roh-roh halus yang mereka puja itu kemudian dimanifestasikan pada arca-arca dewa yang dianut dalam dua agama itu. Tradisi sesaji masih berlangsung pada agama Hindu dan Buddha ini (Soekmono,1993:17-33). Selanjutnya datanglah agama Islam yang mulai berkembang luas di Jawa pada abad ke-16. Penyebaran agama ini dilakukan dengan cara damai dan menggunakan kearifan budaya lokal (Poesponegoro, 1993). Salah satu sarana yang digunakan dalam Islamisasi adalah melalui makanan yang memiliki simbol-simbol dalam kepercayaan Islam. Beberapa makanan itu bukan diciptakan sebagai hal yang baru, akan tetapi dimaknai sesuai dengan agama Islam. Contohnya nasi tumpeng yang sudah ada semenjak Islam belum datang di tanah Jawa (Sholikhin, 2010:52).

Untuk itulah maka diperlukan penggalian makna dan filosofi terhadap kehadiran kuliner dalam setiap upacara tradisional. Ragam kuliner itu merupakan nilai tambah secara ekonomis, sehingga beragam kuliner itu dapat dinikmati oleh masyarakat tidak hanya pada saat kegiatan upacara saja. Keberadaan kuliner perlu diinventarisasi, dideskripsikan latar belakang historis, masyarakat pendukung kuliner, resepresep kuliner dan pemetaan lokasi pembuat kuliner. Dari deskripsi di atas maka akan dapat dilakukan pemetaan kuliner untuk mengokohkan eksistensi Jepara sebagai tempat tujuan wisata kuliner sekaligus sebagai identitas lokal Jepara.

Atas dasar itulah maka artikel ini mengangkat topik tentang jenis-jenis kuliner sesaji dalam upacara tradisi sehingga keberadaan kuliner pada setiap kegiatan yang berbasis budaya dapat tetap eksis dan berkembang. Sebagai produk budaya, keberadaan kuliner dapat mendukung wisata terpadu yang ada di Jepara.

\section{METODE}

Artikel ini merupakan sebuah penelitian deskriptif analitis (Koentjaraningrat, 1989). Penelitian ini menggunakan sumber primer dan sumber sekunder. Sumber primer berupa arsip atau data lain baik tekstual maupun nontekstual. Adapun sumber sekunder diperoleh dari hasil riset sebelumnya (Sulistyono, dkk, 2005) dan berbagai pustaka yang relevan. Oleh karena itu, studi pustaka merupakan langkah yang paling awal agar mendapatkan konsep, teori atau pun data-data awal yang sangat diperlukan dalam penelitian. Studi pustaka digunakan sebagai studi komparasi dalam menjelaskan fenomenafenomena yang sama atau memiliki kemiripan 
dengan objek kajian penelitian, tetapi berbeda lokasi atau pun periodisasi waktunya.

Tahapan yang dilakukan dalam penelitian ini antara lain penggalian data primer berupa arsip atau dokumen dan informasi yang berasal dari informan perwakilan berbagai unsur pemangku kebijakan yang memiliki kepedulian dan komitmen terhadap kuliner lokal di Jepara. Adapun tahapan pengumpulan data yang dilakukan meliputi pengumpulan sumber/data berupa dokumen-dokumen (arsip-arsip kebijakan, gambar, peraturan, dan sebagainya) dan berita surat kabar, oral tradition, observasi faktual di lapangan. Sumber-sumber tersebut diteliti secara kritis supaya kredibel.

Dalam rangka menggali informasi yang berkaitan dengan kuliner lokal dilakukan observasi langsung. Observasi atau pengamatan bertujuan untuk memperoleh deskripsi yang lebih utuh mengenai kuliner dan nilai-nilai yang terkandung untuk dikembangkan, sekaligus mendokumentasi-kan jenis kuliner, latar belakang historis, masyarakat pendukung kuliner, resep-resep kuliner, dan pemetaan lokasi pembuat kuliner. Meskipun dari sisi historis, dokumen atau informasi yang memberitakan tentang kuliner Jepara sangat minim, namun secara faktual kuliner lokal eksis hingga saat ini.

Data penelitian juga dikumpulkan dengan menggunakan teknik wawancara mendalam (indepth interview). Wawancara dilakukan terhadap semua elemen pemangku kepentingan di antaranya penjual dan pembuat kuliner lokal, Dinas Pariwisata, Bappeda, organisasi pengusaha kuliner, penikmat kuliner, masyarakat dan tokoh-tokoh masyarakat yang relevan, serta asosiasi yang terkait.

Indepth interview dilakukan untuk mengetahui warisan budaya yang bersifat nonfisik (intangible) di Jepara berupa kuliner khas Jepara, mendeskripsi jenis-jenis kuliner, latar belakang historis, masyarakat pendukung, resep-resep berikut cara memasaknya, serta pemetaan lokasi terhadap masing-masing jenis kuliner yang telah diinventarisasi. Dalam wawancara ini juga digali fungsi teknis, makna atau nilai budaya, fungsi sosial atau pun arti simbolik dari suatu kuliner tersebut atau fenomena lainnya.

Penajaman pengumpulan data dan informasi dilakukan dengan menggunakan FGD (Focus Group Discussion). Pada kegiatan FGD ini masing-masing individu secara berkelompok saling bertanya, menyampaikan pendapat, persepsi, dan keyakinan terhadap kuliner lokal dan nilai-nilai tradisi yang terdapat dalam simbolisasi kuliner. FGD memberikan kebebasan kepada para peserta yang mewakili berbagai kelompok pemangku kepentingan secara bersamaan baik penjual, masyarakat dan pelaku usaha yang menopang kegiatan, pembuat, penikmat kuliner, organisasi kuliner, tokoh masyarakat yang relevan, dan dinas terkait. Melalui FGD dapat diperoleh akses terhadap kelompok-kelompok pendukung kuliner untuk dieksplorasi lebih mendalam.

Pendekatan antropologis juga digunakan sebagai upaya memfokuskan pada studi-studi etnohistoris yaitu berbagai aktivitas masyarakat, budaya, makna simbolis, dan nilai-nilai tradisi lokal yang di masa sekarang masih berkait atau mencerminkan pengetahuan dan kehidupannya di masa lampau yang mempunyai makna budaya atau tradisi lokal. Adapun pendekatan hermeuneutik digunakan dalam rangka mengungkap semua hasil karya manusia utamanya hasil budaya intangible berupa kuliner yang bermakna, baik individual atau pun kelompok, baik itu berupa persepsi, respon, apresiasi atau pun hasil kreativitasnya, dalam suatu kajian yang bersifat humanistik. Hermeneutik atau interpretif simbolik, yaitu pendekatan yang memposisikan karya tidak sebagai objek atau fakta, tetapi sebagai karya. Keberadaan kuliner akan dapat bercerita banyak dan menyampaikan pesan-pesan yang bermakna simbolik, baik konteksnya dengan benda, lingkungan atau sejarahnya. Adapun yang terpenting dalam penggunaan pendekatan hermeneutika, adalah selalu bertanya tentang sesuatu atau pun makna-makna yang tersembunyi di balik munculnya fenomena sebuah karya manusia tersebut. Artinya kuliner sebagai bagian dari budaya dapat bercerita banyak tentang makna atau nilai yang terkadung dari berbagai versi atau pendekatan. Tentu saja 
fungsi atau pun makna dapat berubah seiring dengan perkembangan waktu. Artinya baik fungsi atau pun makna dari sebuah budaya dapat bergeser sesuai dengan kepentingan manusia tatkala kuliner sebagai bagian budaya masih berfungsi untuk keperluan hidup manusia.

Kuliner sebagai produk ekonomi tentu ada permintaan, ada penawaran. Produsen mempunyai tugas untuk menghasilkan suatu produk agar dapat memenuhi permintaan. Konsumen adalah penikmat kuliner. Konsumen mempunyai kebutuhan dan permintaanpermintaan yang harus dipenuhi dan pemenuhan kebutuhan tersebut dengan sarana uang (Ace Partadiredja, 1985: 22-23). Secara mikro dijelaskan kuliner memberi dampak positif yaitu meningkatkan pendapatan masyarakat lokal. Berkembangnyanya komunitas pedagang kuliner di sekitar lokasi akan menambah pendapatan masyarakat.

Berkembangnya ekonomi kreatif masyarakat Jepara itu secara historis telah menjadi tradisi dan bagian dari aktivitas ekonomi masyarakat Jepara masa lalu. Oleh karena itu, jika ekonomi kreatif di Jepara masih eksis, hal itu menunjukkan bahwa tradisi ekonomi tersebut masih sangat kuat mengakar dalam soft skill masyarakat. Sehingga tidak aneh jika ekonomi kreatif semakin tumbuh dan berkembang di Jepara (Bapeda Jepara-LPEB STIENU Jepara, 2006; Gustami, S.P., 2000; Alamsyah: 2012; Bapeda Jepara, 2012).

Semua data yang telah dikumpulkan melalui metode dan berbagai pendekatan di atas selanjutnya akan diklasifikasikan, dihubunghubungkan atau diakumulasikan antara data satu dengan yang lainnya, dikaitkan antara sumber primer dengan sumber-sumber pustaka atau sumber sekunder sebagai suatu bentuk interpretasi. Lalu semua data tersebut disintesis dalam rangka mengembangkan model yang dapat diaplikasikan.

\section{SEDEKAH LAUT}

\section{Prosesi dan Kuliner Upacara}

Prosesi dan Perlengkapan Upacara Sedekah Laut didahului dengan adanya persiapan yang meliputi pembentukan panitia, pembuatan miniatur perahu sebagai tempat sesaji, pembelian kerbau sebagai salah satu bagian terpenting dalam pelarungan sesaji, pembuatan sesaji yang hanya diperkenankan dibuat oleh keturunan mantan Petinggi ${ }^{l}$ H. Sidik ${ }^{2}$, pemilihan lakon wayang kulit yang dilaksanakan pada 6 Syawal malam dan 7 Syawal setelah pelarungan sesaji $^{3}$, serta puncak pelaksanaan larung sesaji pada 7 Syawal pagi (Wawancara dengan Suhendro, 12 Juli 2016).

Upacara Sedekah Laut di Desa Ujungbatu Jepara berlangsung selama dua hari, yaitu pada 6 dan 7 Syawal, pada tahun 2016 ini bertepatan dengan 12 dan 13 Juli. Pada 6 Syawal atau 12 Juli sifatnya adalah persiapan upacara, sedangkan 7 Syawal atau 13 Juli adalah puncak upacara.

Kegiatan prosesi sedekah laut dengan urutan yang pertama, persiapan upacara yang berlangsung pada 6 Syawal atau 12 Juli 2016, dilakukan untuk mendukung acara inti yaitu pelarungan sedekah laut pada keesokan harinya. Upacara persiapan arak-arakan menggiring kerbau dari Tempat Pelelangan Ikan (TPI) Ujungbatu ke Rumah Pemotongan Hewan (RPH) Jepara berlangsung pada pagi hari jam 7 di TPI Ujungbatu. Sebelum upacara dimulai, kerbau yang hendak disembelih dipersiapkan dan diberi kalung kupat dan lepet. Selain itu disiapkan juga sesaji berupa beras kuning dan jajan pasar. Setelah semua persiapan selesai, peserta upacara persiapan arak-arakan kerbau disiapkan dalam bentuk melingkar.

Urutan kedua, dilakukan arak-arakan menggiring kerbau ke RPH di Jepara diikuti oleh semua peserta upacara dengan berjalan kaki. Di antara peserta arak-arakan itu terdapat pemudapemudi Jepara yang mengenakan pakaian tradisional lurik, diikuti beberapa pemuda yang mendorong alat musik pukul yang mengiringi arak-arakan. Tujuan arak-arakan ini adalah agar masyarakat dapat menyaksikan kerbau yang akan disembelih dan kepalanya akan dilarung. Arakarakan ini baru dilaksanakan pada tahun ini, agar masyarakat turut merasakan bahwa upacara ini adalah milik mereka, masyarakat Jepara (Wawancara dengan Agus Tri Raharjo, 12 Juli 2016).

Urutan ketiga, dilakukan pemotongan kerbau yang dilaksanakan di RPH Jepara yang 
terletak di dekat Kantor Lurah Jobokuto. Daging kerbau selanjutnya dibagi-bagikan kepada masyarakat, sedangkan kepala kerbau disimpan untuk selanjutnya disucikan dan didiberi doa oleh ulama setempat. Setelah diberi doa, selanjutnya kepala kerbu itu dibalut dengan kain mori dan disiapkan dupa.

Urutan keempat, dilakukan pembuatan sesaji yang akan dilarung pada keesokan harinya selain kepala kerbau. Berbagai jenis makanan berupa nasi nuk-nukan, ayam dhekem, ayam panggang, urap dengan tujuh jenis sayuran, sayur bobor kelor, kupat, lepet, buah, jajan pasar, gula pasir, gula jawa, kopi, dan teh, serta berbagai $u b o$ rampe lain seperti sawan laut ${ }^{4}$ yang harus disiapkan dalam berbagai wadah.

Urutan kelima, dilakukan selamatan dan ziarah ke makam Cik Lanang, di Pantai Kartini, Cik Lanang adalah salah satu tokoh legendaris di Jepara. Cik Lanang diceritaka sebagai orang yang dahulu mendiami Pulau Kelor (Slompret Melayu, 12 dan 17 Agustus 1893). ${ }^{5}$ Pulau itu dipinjamkan kepadanya karena jasanya dalam membantu Hindia Belanda pada perang Bali.



Gambar 4. Contoh sesaji yang sudah ditata.

(Sumber: Dokumentasi Peneliti, 2016).

Pada satu abad yang lalu, pusat keramaian lomban berlangsung di Teluk Jepara dan berakhir di Pulau Kelor yang masih terpisah dengan daratan di Jepara (Hindia Belanda, 1868). Pada saat ini, Pulau Kelor adalah kompleks Pantai Kartini. Oleh karena itu, tidak mengherankan jika dalam prosesi lomban atau sedekah laut ini selalu diadakan Selamatan dan ziarah ke makam Cik Lanang, di Pantai Kartini, pada waktu ba'da Asyar.
Urutan keenam, dilakukan selamatan dan ziarah ke makam Kyai Ronggomulyo, sesepuh desa. Kyai Ronggomulyo adalah seorang Rangga, pemimpin. Beliau adalah salah satu prajurit Pangeran Diponegoro yang melarikan diri, menyelamatkan diri hingga di Jepara, dan membuka Desa Ujungbatu. Oleh karena itu, hingga sekarang makam Kyai Ronggomulyo tetap dihormati dan setiap menjelang upacara sedekah laut selalu diziarahi.

Urutan ketujuh, dilakukan pentas wayang kulit semalam suntuk di TPI Ujungbatu, mulai ba'da Isya. Lakon yang dimainkan adalah Raden Gathutkaca Winisudho dengan Dalang Ki Purwanto dari Bandengan Jepara.

Adapun upacara inti pada 7 Syawal atau 13 Juli 2016 meliputi pertama, Upacara pelepasan sesaji di TPI Ujungbatu oleh Bupati Jepara. Sebelum sesaji dilepas di laut, dilakukan upacara seremonial terlebih dahulu yang antara lain menampilkan tari-tarian nelayan. Selanjutnya dipanjatkan doa dan baru dilepas oleh Bupati Jepara. Kedua, Pelarungan sesaji dengan menggunakan dua buah kapal. Kapal-kapal itu dinaiki oleh pejabat dan tamu undangan. Salah satu kapal membawa miniatur kapal yang berisi sesaji seperti pada gambar berikut ini.

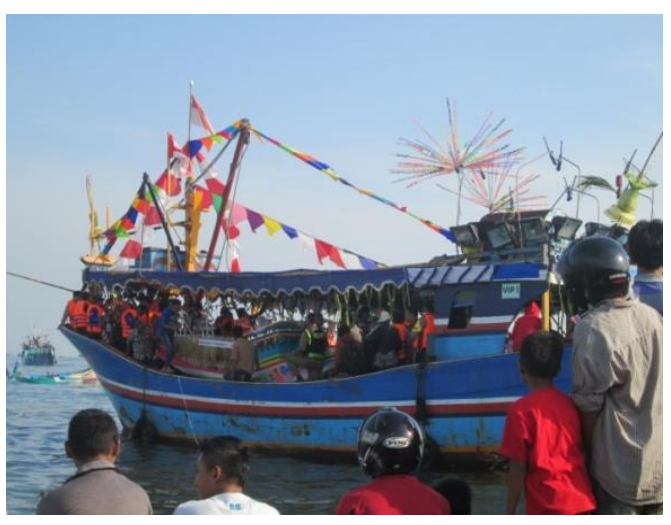

Gambar 5. Kapal sesaji dibawa menuju tempat pelarungan.

(Sumber: Dokumentasi Peneliti, 2016)

Pelarungan sesaji itu diikuti pula oleh puluhan kapal nelayan yang nanti setelah pelarungan selesai akan memeriahkan pesta lomban. Ketiga, Pesta lomban merupakan puncak acara dari pekan Syawalan yang diselenggarakan pada delapan Syawal atau satu minggu setelah Idul Fitri. Sajian utama pada 
pesta ini adalah kupat, sehingga sering pula dinamakan sebagai bodo kupat. Menurut masyarakat Jepara, lomban berasal dari kata "lomba-lomba" atau "lelumban" yang keduanya memiliki arti yang sama, yaitu bersenang-senang. Mereka bersenang-senang setelah menjalani puasa selama sebulan penuh di bulan Romadlon. Di dalam pesta lomban ini, terjadi "perang teluk" dengan menggunakan kupat dan lepet sebagai pelurunya. Setelah sesaji yang terdapat pada miniatur kapal itu dilepas, maka para nelayan banyak yang menceburkan diri ke laut untuk berebut mengambil sesaji dan dimulailah "perang teluk" itu dari kapal-kapal lainnya. Perang itu diakhiri dengan mendaratkan perahu ke Pantai Kartini, yang dahulu merupakan Pulau Kelor, tempat kediaman Cik Lanang.

Keempat, pergelaran wayang di TPI Ujungbatu dengan lakon Sri Sadhono yang dimainkan oleh Dhalang Ki Suhani. Kelima, Pesta Rakyat di Pantai Kartini dimulai setelah acara lomban. Pada saat itu, di Pantai Kartini diselenggarakan berbagai acara, antara lain festival kupat-lepet, yaitu pertunjukan kesenian yang diakhiri dengan perebutan kupat-lepetyang terdapat dalam dua buah gunungan kupat-lepet yang berisi sejumlah tahun yang menyelenggarakan. Oleh karena tahun ini adalah tahun 2016, maka sejumlah itu pula kupat dan lepet yang berada dalam gunungan. Berbagai hiburan dan aneka jajanan tumpah ruah di Pantai Kartini menyambut kedatangan para wisatawan. Hari itu di Jepara merupakan pesta rakyat. Di berbagai tempat terdapat wisatawan domestik yang menyelenggarakan bodo kupat.

\section{Ragam Sesaji dan Makna Kuliner}

Ragam hias sesaji meliputi pertama, miniatur perahu untuk membawa sesaji berupa kepala kerbau dan beberapa jenis saji-sajian yang diletakkan di atas tambir yang dihias. Tambir berhias daun pisang sebagai tempat sesaji digunakan untuk menempatkan sesaji. Tambir itu dialasi dengan daun pisang, dan pada bagian tepinya diberi hiasan dari daun pisang yang dibentuk menjadi segi tiga. Kedua, cobek untuk tempat menyalakan dupa. Ketiga, kuali bertutup untuk meletakkan sesaji berupa beras kuning, gula pasir, gula batu, gula merah, kopi, teh, dan jahe. Keempat, Mangkuk kecil untuk wadah sayur, lauk, dan boreh. Mangkuk ini berjumlah delapan untuk mewadahi delapan jenis masakan, yaitu sayur kunci daun kelor, gesek, cengkaruk gimbal, cengkaruk keno, sambal gepeng, garam, daging kerbau, dan sawan laut. Kelima, nampan dan mangkuk plastik untuk wadah saji-sajian. Gambaran detail tampak pada Gambar 6 dan 7.



Gambar 6. Mangkuk kecil untuk wadah sayur, lauk, dan boreh.

Sumber: Dokumentasi Peneliti, 2016

Keenam, dua gunungan kupat dan lepet sebagai pelengkap festival kupat-lepet di Pantai Kartini yang diperebutkan oleh peserta pesta rakyat. Setelah diresmikan oleh Bupati Jepara, maka gunungan kupat-lepet itu kemudian diperebutkan oleh warga yang mengikuti upacara tradisi Lomban di pantai Kartini.

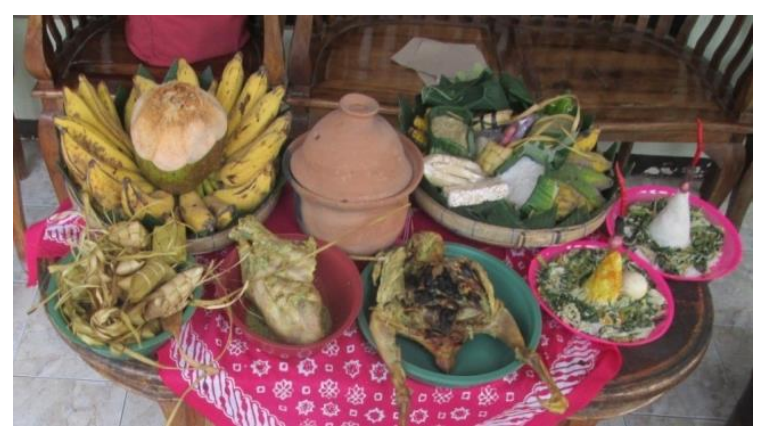

Gambar 7. Mangkuk plastik dan nampan plastik untuk wadah sesaji.

Sumber: Dokumentasi Peneliti, 2016.

Semua kuliner sesaji yang merupakan kesukaan dhanyang Laut Utara untuk upacara Sedekah Laut itu diletakkan pada miniatur kapal, selanjutnya akan dilarung di Laut Utara. Makna dari sesaji itu menggambarkan adanya hubungan 
antara laut dan daratan, dengan ditunjukkannya adanya makanan dari laut berupa gesek dan sawan laut, sebagai obat untuk mencegah timbulnya tuah yang diakibatkan oleh gangguan makhluk halus dari laut; dan berbagai jenis makanan yang terbuat dari bahan-bahan yang diperoleh di darat. Pelarungan sesaji itu merupakan salah satu cara bagi masyarakat nelayan di Jepara mengucapkan terima kasih kepada Laut Jawa, yang telah memberikan rizki selama satu tahun yang telah lewat, dan memohon agar pada tahun yang akan datang rizki dari laut berupa ikan-ikan itu tetap melimpah (Wawancara dengan $\mathrm{Hj}$. Iskarimah pada 12 juli 2016)

\section{Hari Jadi Kota Jepara: Prosesi dan Kuliner}

Hari Jadi Jepara atau Hari Ulang Tahun (HUT) Jepara adalah salah satu rangkaian kegiatan di Jepara. Penetapan HUT Jepara pada 10 April 1549, adalah berdasarkan Peraturan Daerah Tingkat II Jepara Nomor 9 Tahun 1988, tentang Hari Jadi Jepara. Penetapan peraturan daerah tersebut mengacu pada penobatan Putri Retna Kencana, yang dinobatkan sebagai penguasa Jepara dengan nama Nimas Ratu Kalinyamat. Beliau adalah putri Sultan Trenggono, Raja Kerajaan Demak. Tahun penobatan itu ditandai oleh candra sengkala yang berbunyi trus karya tataning bumi yang berarti bekerja keras terus untuk membangun daerah (Panitia Penyusun Hari Jadi Jepara, 1988).

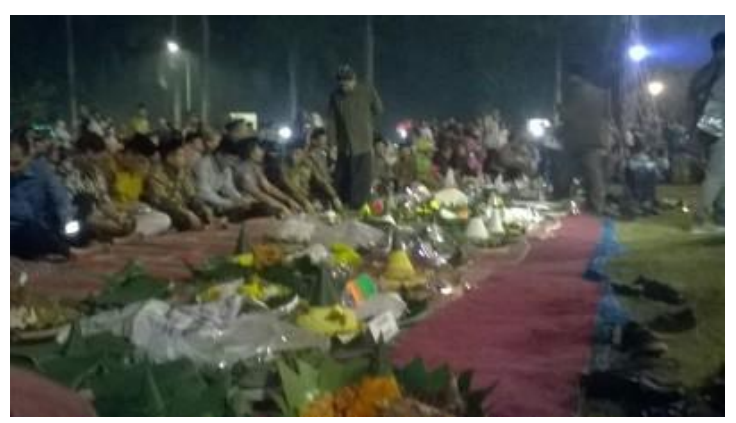

Gambar 10. Selamatan Wilujengan Negari di Alun-alun Jepara.

Sumber: http://berita.suaramerdeka.com/hutjepara-467-tumpeng-dihidangkan, 2016.

Prosesi dan perlengkapan upacaranya pertama, Wilujengan Negari adalah prosesi ruwatan sebagai simbol pembersihan diri bangsa dan negara (Jepara). Acara ini diselenggarakan di alun-alun Jepara pada hari Jumat malam Sabtu, 8 April 2016. Pada acara itu setidaknya ada 467 tumpengsebagai simbol hari jadi Kota Jepara dan acara ini sekaligus menandai hari pertama Festival Kartini dan perayaan hari jadi Jepara di tahun 2016. Berikut ini gambar yang menunjukkan berlangsungnya acara tersebut.

Kedua, prosesi sebelum Kirab Budaya di Pendopo Kabupaten Jepara. Prosesi awal sebelum prosesi kirab budaya, yang dimulai dari pendapa, sedikitnya menampilkan sendratari Laskar Kalinyamat yang dipentaskan oleh 14 penari. Kemudian dilanjutkan dengan penyerahan luwur dari Bupati Jepara kepada tokoh pemeran Ratu Kalinyamat. Ketiga, Kirab Budaya Hari Ulang Tahun Jepara dengan menghadirkan sosok Ratu Kalinyamat saja. Kirab itu digelar mulai dari Pendapa Kabupaten Jepara hingga ke makam Mantingan Kecamatan Tahunan, Jepara. Keempat, prosesi membuka dan mengganti luwur dilaksanakan di cungkup ${ }^{6}$ makam Sultan Hadirin dan Ratu Kalinyamat di kompleks makam Mantingan. Prosesi ini dipimpin Bupati Jepara dan dilakukan beberapa pemangku kepentingan yang berkepentingan. Kelima, selamatan di depan Masjid Mantingan dengan menu nasi tumpeng.

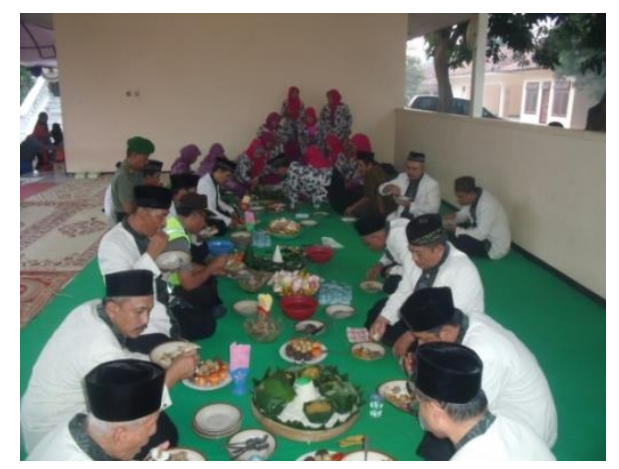

Gambar 11. Selamatan sebagai tanda selesainya prosesi acara HUT Jepara.

Sumber: Dokumentasi Desa Mantingan, 2016.

Adapun peralatan atau penunjang upacara antara lain. Pertama, luwur baru dari pengrajin dan penjahit dari Troso, yaitu Pak Mashudi. Kedua, nasi tumpeng yang disajikan pada upacara Wilujengan Negari di alun-alun Jepara dan upacara selamatan di depan Masjid 
Mantingan. Pada upacara Wilujengan Negari, jumlah tumpeng sebanyak tahun usia Jepara, maka untuk upacara selamatan di depan Masjid Mantingan jumlah tumpengnya disesuaikan dengan anggaran dan kemampuan Pemerintahan Desa Mantingan (lihat Gambar 12).

Sementara itu, ragam dan makna kulinernya antara lain. Pertama, tumpeng berupa nasi putih yang dibentuk kerucut, yang penyajiannya dilengkapi dengan lauk pauk. Di dalam masyarakat Jawa, tumpeng berarti "metua dalan kang lempeng." Dalam hal ini yang dimaksud adalah "lewatlah jalan yang lurus," yaitu jalan yang dibawa oleh Rasulullah, yaitu agama Islam. Kedua, urap dalam bahasa Jawa sering disebut dengan gudhangan atau kuluban. Keduanya adalah lauk yang terbuat dari sayuran yang direbus kemudian dicampur dengan kelapa parut yang berbumbu. Gudhangan bermakna harapan untuk hidup bahagia. Ketiga, kering tempe sebagai lambang kesederhanaan dan kesahajaan. Keempat, sambel goreng kentang melambangkan kegairahan hidup yang diwarnai dengan rasa pedas, tetapi sedap dan nikmat. Kelima, ayam dhekem aatau ingkung yang dimasak utuh. Oleh masyarakat Jawa, ingkung diartikan sebagai "enggala jungkung" dimaksudkan agar bersegera bersujud atau beribadah sepenuhnya kepada Allah. Orang Jawa juga memaknai ingkung dengan "enggala manekung," yaitu bersegeralah berdzikir kepada Allah. Dengan demikian, ingkung bagi masyarakat Jawa adalah ajakan untuk segera beribadah sepenuhnya kepada Allah dengan menjalankan sholat dan berdzikir (Endraswara, 2003:199). Keenam Gesek atau ikan kering goreng menandai bahwa daerah yang bersangkutan adalah daerah penghasil ikan, yaitu di daerah pesisir.

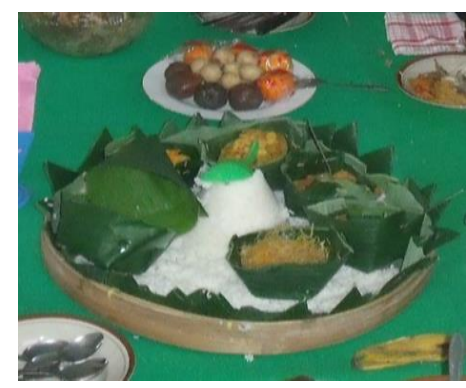

Gambar 12. Nasi tumpeng.

Sumber: Dokumentasi Desa Mantingan, 2016.

\section{Perang Obor: Prosesi dan Perlengkapan Upacara}

Perang Obor merupakan atraksi perang dengan menggunakan daun kelapa kering (blarak, Jw) yang dibakar dan dihantamkan kepada peserta lainnya. Menurut cerita tutur, tradisi perang obor ini berasal pada zaman Kerajaan Demak, sehingga upacara tradisi ini dikaitkan dengan upaya islamisasi di kawasan ini. Pada mulanya, tujuan diselenggarakannya upacara tradisi ini adalah untuk mengusir segala roh jahat yang mendatangkan penyakit. Pada perkembangannya, upacara yang diselenggarakan pada setiap puncak panen raya ini, yaitu pada setiap malam Selasa Pon bulan Dzulhijjah, juga merupakan upacara sedekah bumi Desa Tegalsambi yang bertujuan untuk meluapkan rasa syukur masyarakat setelah mereka menikmati hasil panen yang melimpah. Upacara itu dilengkapi pula dengan pergelaran wayang kulit dan prosesi mengarak empat pusaka ${ }^{7}$ yang dipercayai sebagai warisan Sunan Kalijaga kepada Kabayan Tegal Sambi.

Sebelum acara Perang Obor dimulai, terlebih dahulu diadakan selamatan di tujuh tempat yang dikeramatkan oleh masyarakat Tegalsambi. Selanjutnya pada hari Senin Pahing dilakukan penyembelihan kerbau jantan muda yang belum pernah dipakai untuk membajak di rumah kepala desa. Menjelang malam Selasa Pon, Bayan sebagai seksi keamanan desa, menaruh sesajen yang diperuntukkan bagi para dhanyang yang dipercayai ikut menentukan keselamatan Desa Tegalsambi. Sesajen itu berupa darah kerbau, sebagian jerohan, dan daging yang sudah dimasak yang dimasukkan dalam kendhil. Pada malam harinya, upacara dimulai dengan diawali doa mememohon restu kepada dhanyang penguasa Desa Tegalsambi, pembakaran kemenyan, serta dengan diiringi gamelan Kebo Giro mulailah perang obor itu di sepanjang jalan Desa Tegalsambi.

Urut-urutan upacara tradisi Perang Obor menurut penuturan Lurah Tegalsambi adalah pertama, melakukan ziarah kubur atau barikan pada makam-makam leluhur. Ziarah kubur yang dilakukan pada beberapa makam leluhur dimaksudkan sebagai cara-cara penghormatan 
atas jasa-jasa yang telah dilakukan. Prosesi ziarah berlangsung selama selapanan atau 35 hari, dengan berkunjung pada beberapa makam, antara lain Mbah Tegal, Surya Manis, Mbah Gemblong, Tunggul Wulung, Rapto, Sudiman, Datuk Sulaiman dan Towi Kromo. Dari beberapa makam tersebut ada tujuh makam yang dianggap penting. Kedua, awal Perang Obor yang diawali dengan selamatan pada ketujuh makam terpenting, kemudian dilanjutkan dengan penyembelihan seekor kerbau jantan muda yang belum pernah dipakai untuk membajak (Wawancara dengan Slamet Riyadi, pada 13 Juli 2016).

Dalam melakukan aktivitas ziarah disediakan nasi, ingkung ayam, sayur-sayuran serta buah-buahan yang merupakan hasil bumi dari desa setempat. Khusus pada waktu ziarah ke makam Mbah Tegal, disiapkan dhekem kepiting. Bisanya yang dimasak dhekem adalah ayam, dengan cara memasak opor namun kuahnya lebih sedikit dan ayam dimasak dalam kondisi utuh. Dhekem kepiting, mempunyai bumbu yang sama dengan dhekem ayam namun ayamnya diganti kepiting. Hal ini dilakukan karena ada kepercayaan dari masyarakat setempat bahwa kepiting merupakan makanan kesukaan dari Mbah Tegal.

Makanan yang juga menjadi hidangan khas pada waktu tradisi Perang Obor adalah kintelan. Makanan ini terbuat dari beras ketan dimasak kemudian dihidangkan dengan kuah gula aren. Makanan ini dimaknai sebagai simbol pemersatu dan kerukunan. Sebelum dilaksanakan Perang Obor, masyarakat setempat dengan dikoordinasi perangkat desa menyiapkan sesaji untuk tujuh makam besar dan 15 makam kecil. Adapun sesaji tersebut berupa racikan yang berupa kumpulan berbagai makanan yaitu gemblong, wajik, bubur abang putih, sirih, pisang klethuk, pisang raja, sekar telon, kluwek, telur ayam.

Sesajen yang digunakan adalah darah kerbau, sate jeroan dan daging mentah. Sesaji ini dihidangkan dengan maksud untuk dhanyang yang dipercayai masyarakat ikut membawa ketentraman masyarakat sekitar. Dhanyang tersebut diibaratkan sebagai seorang wanita cantik yang bernama Mbah Nyai Ki Songgo
Buwono. Adanya kepercayaan bahwa dhanyangnya seorang wanita, maka di dalam sesaji juga disertakan peralatan berdandan, antara lain kaca pengilon, bedak, pemerah bibir serta minyak wangi dan lain-lainnya yang dianggap peralatan kecantikan wanita. Kegiatan tersebut juga ditunjang peralatan upacara.

\section{Ragam dan Makna Kuliner}

Di antara ragam kuliner yang disajikan dalam prosesi upacara Perang Obor di antaranya kintelan. Makanan ini akan disosialisikan dalam setiap kegiatan saat tamu-tamu resmi yang berkunjung ke desa tersebut maupun melalui pameran. Makanan ini dipandang mempunyai perpaduan yang gurih karena terbuat dari ketan serta disiram dengan kuah gula aren, cita rasanya menjadi makanan yang secara umum disukai masyarakat umum.

Di samping itu adanya keyakinan bahwa dalam makanan tersebut terkandung pengharapan atau semacam doa akan kesehatan, usaha lancar, serta harapan lain yang bersifat positif cepat dapat jodoh dan lain-lain.

Menurut penuturan Lurah Tegalsambi, tradisi ini sudah seharusnya dilestarikan sebagai bentuk penghormatan terhadap orang-tua yang telah menjalankan tradisi secara turun-temurun. Tradisi ini bila dikaitkan dengan upaya menarik wisatawan belum memberikan hasil yang menggembirakan. Namun kalau dilihat dari sisi pelestarian budaya amat positif. Meskipun biaya yang harus dipersiapkan warga cukup besar sekitar 50-60 juta, namun nilai-nilai kebaikan lokal yang akan disosialisasikan sehingga mempunyai pengaruh yang besar bagi masyarakat setempat.

\section{Pesta Baratan di Kecamatan Kalinyamatan: Prosesi dan Kuliner}

Tradisi menyalakan lampu uplik atau menaruh obor atau menaruh impes (lampion) di depan rumah pada malam nisfu sya'ban sudah menjadi kebiasaan masyarakat Jepara. Bahkan bagi anakanak, pada malam tersebut, mereka berkeliling kampung sambil membawa obor atau lampion. Tradisi ini awalnya merupakan suatu kegiatan untuk nguri-nguri budaya melalui festival 
lampion atau impes (kembung-kempes). Impes ini terbuat dari kertas sejenis krep yang bisa dilipat sehingga bisa dilipat. Karena bisa diimpeskan, maka disebut impes. Di dalam lampion biasanya diberi lilin untuk penerangan (Wawancara dengan Muhamad Asyari; Winahyu Widayati, Agustus 2016). Acara ini mulai digelar cukup besar pada 2004 dengan ditandai arakarakan lampu lampion terpanjang. Event ini masuk Museum Rekor Indonesia, karena masyarakat yang membawa lampion dikategorikan terbanyak pada saat itu. Sejak penyelenggaraan tersebut, pesta Baratan rutin digelar dan menjadi kegiatan tahunan masyarakat (Wawancara dengan Winahyu Widayati, Agustus 2016).

Menurut legenda, ada dua versi yang mendasari tradisi Baratan. Versi pertama, tentang Sultan Hadirin (Sayyid Abdurrahman Ar Rumi) yang berperang melawan Aryo Penangsang dan terluka. Kemudian sang istri Nyai Ratu Kalinyamat (Retno Kencono) membawanya pulang ke Jepara dengan dikawal prajurit dan dayang-dayang. Di sepanjang jalan banyak desa yang dilewati rombongan dan kemudian diberi nama. Salah satu contohnya adalah saat rombongan melewati suatu desa, mendadak tercium bau harum semerbak (gondo) dari jasad Sultan, maka desa tersebut sekarang kita kenal dengan nama Purwogondo (http://ongkorongko. blogspot.co.id/2016/05/ pesta-baratan.html). Kedua, Sultan Hadirin setelah berperang melawan Aryo Penangsang, Sultan Hadirin tewas dan jenazahnya dibawa pulang oleh isterinya (Ratu Kalinyamat) ke Jepara. Peristiwa itu berlangsung malam hari, sehingga masyarakat di sepanjang jalan yang ingin menyaksikan dan menyambut rombongan Ratu Kalinyamat dengan membawa alat penerangan berupa obor (http://ongkorongko.blogspot.co.id/2016/05/pesta-baratan. html).

Dalam konteks kekinian, pesta Baratan yang diselenggarakan pada malam nisfu sya'ban prosesinya dimulai setelah salat Maghrib di mushola atau masjid. Pascasalat, masyarakat biasanya tidak langsung pulang. Mereka tetap berada di masjid atau musholla untuk berdoa bersama. Diawali dengan membaca surat Yasin tiga kali secara bersama-sama dilanjutkan salat isya' berjamaah. Setelah itu mereka memanjatkan doa nishfu sya'ban yang dipimpin ulama atau kiai setempat. Setelah berdoa, mereka makan (bancaan) nasi puli dan melakukan arak-arakan dengan membawa impes atau lampion. Rumah-rumah penduduk dipasangi impes dalam menyambut malam nishfu sya'ban tersebut. Kegiatan ini telah menjadi tradisi di desa-desa yang terdapat di sebagian masyarakat Jepara (https://id.wikipedia. wiki/Pesta_Baratan). org/

Kata baratan berasal dari sebuah kata Bahasa Arab, yaitu baraah yang berarti keselamatan atau barakah yang berarti keberkahan. Tradisi ini untuk menjaga supaya masyarakat tidak terkena bahaya atau penyakit. Berdasar tradisi lisan, Baratan berasal dari dari kata baro'atan yang berarti lembaran. Artinya, pada 15 Sya'ban merupakan pergantian lembaran catatan amal perbuatan manusia menjelang Ramadhan. Lembaran itu habis untuk mencatat amal yang lama diganti dengan yang baru. Ramadan harus diisi dengan berbagai amalan. Dengan dinyalakan obor di depan rumah dan membawa obor keliling kampung, maka harapan catatan amal warga sekampung menjadi lebih terang atau baik. Manusia yang telah mempersiapkan penyelesaian tugas, yaitu mematuhi perintah syariat agama dan menjauhi larangan-larangan Allah SWT. Pelaksanaan pesta Baratan ini merupakan kombinasi antara tradisi leluhur dengan tradisi Islam yaitu sebagai simbolisasi peristiwa pembunuhan Sultan Hadlirin (http://www.murianews.com/2016/ 05/20/83427/pesta-baratan-khas-kalinyamatanjepara-lebih-meriah-tahun-ini.html).

Kegiatan pesta Baratan, lebih banyak dipusatkan dan dimulai dari Masjid Al Makmur Desa Kriyan Kecamatan Kalinyamatan dan berakhir di pendopo Kecamatan Kalinyamatan. Dalam acara Baratan seorang yang berperan sebagai Ratu Kalinyamat menjadi sentral arakarakan, diikuti para dayang, prajurit, terbangan sholawatan dari daerah sekitar, dan peserta anakanak yang membawa lampion, obor, maupun tetabohan-tetabohan. 
Ritualnya sederhana, sebelum dimulai arak-arakan, peserta karnaval shalat Maghrib berjamaah dan peserta prosesi tidak langsung pulang. Mereka tetap berada di masjid atau mushola untuk berdoa bersama, lalu dilanjutkan pembacaan surat Yasin sebanyak tiga kali secara bersama-sama dengan tujuan agar para pembacanya diberikan panjang umur, mendapatkan rizki yang melimpah dan tetap dalam keadaan Iman dan Islam hingga akhir hayat. Kegiatan tersebut ditutup dengan doa nisfu sya'ban yang dipimpin oleh kyai atau ulama setempat. Kemudian diteruskan dengan bancaan, dengan menyantap bersama makanan khas daerah tersebut yang berupa makanan puli. Setelah itu dilanjutkan dengan shalat Isya berjamaah. Harapannya catatan amal warga diharapkan terang alias baik (http://ceritaanda. viva.co.id/news/read/427323-pesta-baratan-dikota-jepara).

Dari halaman masjid Al Makmur Desa Kriyan ini, ribuan orang dengan membawa lampion mengarak simbol Ratu Kalinyamat menuju pusat Kecamatan. Mereka meneriakkan yel-yel ritmis "tong-tong ji, tong tong jeder, pak kaji nabuh jeder", dan sebagian lainnya melantunkan shalawat Nabi. "Tong-tong ji", maknanya sesuatu terjadi dan menewaskan seorang yang berpengaruh. "tong-tong jeder" maknanya sesuatu itu akan menjadi persoalan yang besar (Geger Tanah Jawa). Secara etimologi, "Tong Tong Ji Tong Tong Jeder" memiliki makna peringatan kepada seluruh masyarakat tentang terjadinya satu peristiwa yang akan membuat gaduh seluruh tanah Jawa (khususnya Jepara). " $J i$ itu siji (satu), "jeder" itu gemuruh (geger/kegemparan). Melalui acara baratan dapat memupuk tali silaturohmi di antara warga Kalinyamatan pada Khususnya dan Jepara pada umumnya (http://ongkorongko. blogspot.co.id/2016/05/pesta-baratan.html).

Prosesi arak-arakan pesta Baratan dimulai dengan pembukaan acara oleh Bupati Jepara. Peserta Baratan kemudian berjalan menuju garis finish. Dalam prosesi ini, Ratu Kalinyamat kadang naik kereta kuda, kadang naik kuda dengan memakai baju merah dengan sanggulnya yang khas dan rambut yang tergerai. Di kanan kirinya, para pengawal mengapit Ratu Kalinyamat (http://www.murianews.com).

\section{Ragam Kuliner dan Maknanya}

Dalam tradisi ini juga disajikan makanan khas di antaranya nasi puli, ketan, dan gender (https://id.wikipedia.org/wiki/Pesta_Baratan). Nasi puli, sebagai salah satu kelengkapan ritual, yang konon berasal dari bahasa Arab afwun li berarti ampuni diriku. Arti secara luasnya adalah memberi teladan untuk setiap manusia, supaya sadar diri dan melakukan tobat nasuha atau tobat yang sesungguhnya, dengan tidak mengulangi kesalahan dan dosa yang pernah dilakukannya. Mereka berpandangan bahwa nisfu sya'ban merupakan penutupan buku catatan amal bagi umat Islam.

Satu minggu sebelum acara pesta Baratan dimulai, di kantor Kecamatan Kalinyamatan dilakukan selamatan. Adapun makanan yang digunakan dalam acara selamatan ini adalah nasi yang dimasukkan ke dalam nampan mika dengan lauk tahu, tempe, urap sayur, dan suwiran ayam ingkung. Makanan tersebut kemudian dibagikan kepada para peserta selamatan.

Dalam prosesi pesta Baratan ini terdapat makanan khas, di antaranya puli, bongko ceblok, dan ketan. Puli terbuat dari bahan beras, ketan dan blengyaitu campuran garam mineral dengan konsentrasi tinggi yang dipakai dalam pembuatan beberapa makanan tradisional Jawa seperti karak dan gender. Agar rasanya kenyal, maka beras dicampur dengan bleng. Proses pembuatannya yaitu dengan cara dikukus kemudian ditumbuk halus dan dimakan dengan kelapa parut yang dibakar atau tanpa dibakar. Puli terbuat dari bahan beras yang ditumbuk halus dan dimakan dengan kelapa yang diparut. Kelapa parut sebagai campuran puli ini ada yang dibakar dan tidak dibakar, tentu dengan rasa yang berbeda. Kata puli berasal dari Bahasa Arab afwu lii, yang berarti memohon maaf. Filosofi dari puli dimaksudkan untuk memberi teladan bagi setiap manusia, supaya sadar diri dan melakukan tobat Nasuha atau tobat yang sesungguhnya, dengan tidak mengulangi kesalahan dan dosa yang pernah dilakukannya (http://budayaIndonesia.org/TradisiBaratan/). 


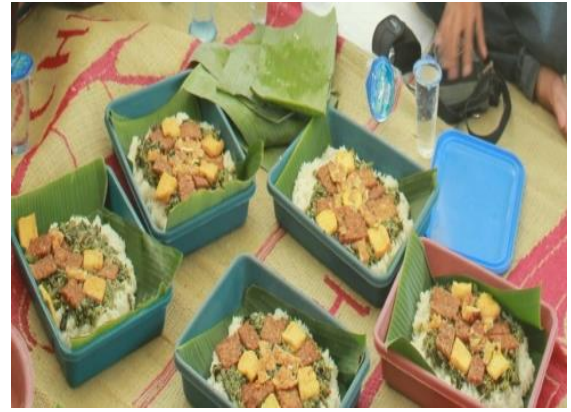

Gambar 13. Aneka Makanan untuk Selamatan Sumber: Dokumentasi Panitia Pesta Baratan 2014

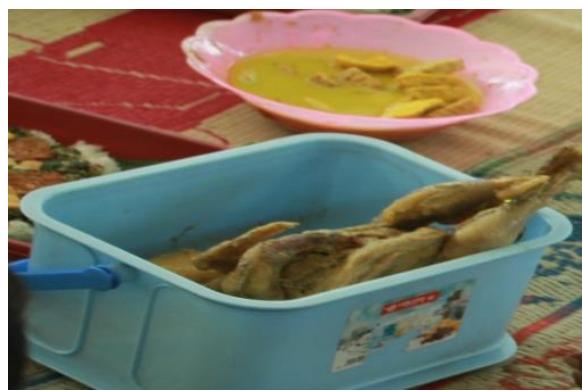

Gambar 14. Ayam utuh (ingkung) untuk Selamatan Sumber: Dokumentasi Panitia Pesta Baratan, 2014

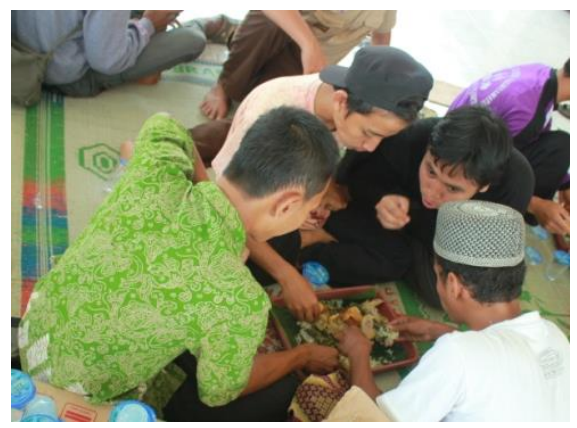

Gambar 15. Makan Nasi Bersama (Ngepung)

Sumber: Dokumentasi Panitia Pesta Baratan, 2014

Selain puli, bongko ceblok juga menjadi makanan dalam kegiatan tersebut. Bongko ceblok merupakan makanan berbahan tepung beras, garam, santan, dan gula Jawa yang mengandung filosofi. Proses pembuatannya dengan mencampur semua kecuali gula Jawa, lalu diuleni sampai kesat kemudian dimasukkan ke dalam daun pisang. Di dalamnya dimasukkan atau diceblok gula Jawa kemudian dikukus kurang lebih satu jam. Secara detail filosofinya berupa, tepung beras yang berwarna putih digambarkan sebagai tubuh manusia, gula Jawa digambarkan sebagai rah atau darah, dalam arti keseluruhan adalah tubuh manusia dicebloke atau ditaruh roh manusia yang fitrah, kemudian bungkus daun disimbolkan sebagai kain kafan atau kematian (lihat Gambar 16), sekaligus menyimbolkan siklus hidup manusia dari mulai diberi nyawa hingga kembali ke sang pencipta (http://budaya-indonesia.org/TradisiBaratan).

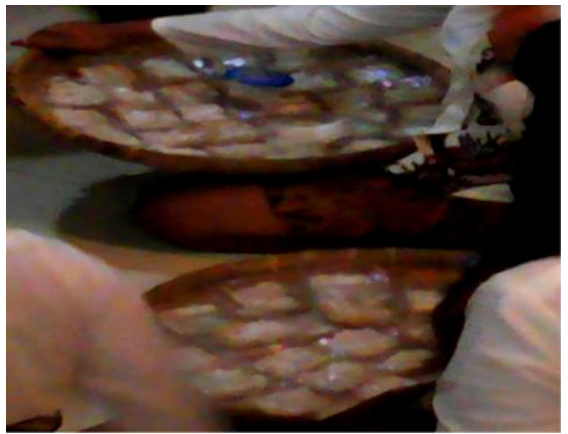

Gambar 16. Puli yang dibawa oleh Dayang Sumber: Lembayung Production, 2016.

Adapun ketan terbuat dari beras ketan putih yang telah dimasak. Ketan ini kemudian ditaburi garam sedikit dan kelapa. Campuran antara kelapa, ketan, dan garam kemudian dibawa ke masjid serta ada pula yang dibagikan kepada tetangga sekitar. Secara etimologi, kata ketan artinya ngiket setan pada bulan nisfu sya'ban supaya tidak ada yang mengganggu ketika memasuki bulan ramadhan. Baik ketan, bongko ceblok, dan puli setelah dibungkus ada yang ditaruh di tampah atau tampah atau mika (Wawancara dengan Muhamad Asyari, Agustus 2016).

Secara detail filosofinya berupa, bahan bongko ceblok berupa tepung beras yang berwarna putih digambarkan sebagai tubuh manusia, gula digambarkan sebagai rah atau darah, dalam arti keseluruhan adalah tubuh ditaruh roh manusia yang fitrah, yang kemudian bungkus daun disimbolkan sebagai kafan atau kematian (http://budaya-indonesia.orgTradisiBaratan/).

Pada 2015, makanan puli diikutkan dalam prosesi dalam bentuk gunungan. Model penataan puli adalah makanan tersebut dibungkus segitiga dengan plastik, lalu ditata satu-satu menyerupai gunungan setinggi satu meter. Makanan ini kemudian dibagikan kepada warga masyarakat sepanjang perjalanan prosesi dari Masjid makmur Kriyan menuju kantor Kecamatan Kalinyamatan setelah didoakan oleh kyai setempat, Gunungan tersebut dipikul oleh 4 
orang. Gunungan ini ditata menggunakan bambu selama setengah hari. Masyarakat berebut mengambil puli sebagai tanda ngalap berkah supaya selamat (Wawancara Soni Hidayat, Agustus 2016).

\section{SIMPULAN}

Jepara mempunyai berbagai tradisi budaya yang masih direalisasikan oleh masyarakat pendukungnya. Event budaya tersebut menjadi ritual, hiburan masyarakat lokal, serta dapat menjadi salah satu destinasi wisata budaya di Jepara. Keberadaan tradisi budaya didukung oleh pemerintah daerah, pemerintah desa, dan komunitas pendukungnya. Dalam setiap tradisi budaya di Jepara seperti pesta lomban, hari jadi kota Jepara, perang obor, pesta Baratan, dan tradisi yang lain terdapat sajian kuliner yang dipercaya mengandung berkah. Sajian kuliner ini terdiri dari berbagai ragam jenis makanan lokal yang dibuat oleh masyarakat pendukungnya. Keberadaan kuliner yang tersaji sejak sebelum acara, proses, hingga sesudah acara menjadi salah satu menu andalan yang diperebutkan oleh masyarakat oleh penduduk karena dipandang mmepunyai nilai berkah.

Keberadaan kuliner dalam setiap tradisi budaya mempunyai peran strategis dalam mendukung keberadaan upacara. Kuliner yang tersaji mempunyai mengandung deskripsi historis dan makna filosofi. Oleh karena itu, kuliner yang berbasis budaya ini perlu dilestarikan, dikembangkan, dan komunitas pendukungnya perlu diberdayakan dalam kegiatan wisata budaya agar mempunyai nilai ekonomi dan menggerakkan ekonomi lokal.

\section{CATATAN}

${ }^{1}$ Petinggi adalah sebutan untuk kepala desa di Jepara ${ }^{2}$ Pembuat sesaji itu adalah ibu $\mathrm{Hj}$. Iskarimah, putri pertama Haji Sidik. Wawancara dengan Fredy Santoso Petinggi Ujungbatu, pada 12 Juli 2016.

${ }^{3}$ Menurut Pak Fredy, lakon wayang pada 6 Syawal malam adalah Raden Gathutkaca Winisudha dengan dalang Ki Purwanto dari Bandengan Jepara. Sementara itu, untuk 7 Syawal setelah pelarungan, lakonnya adalah Sri Sadhono yang dibawakan oleh dalang Ki Suheni (Wawancara dengan Fredy Santoso VM, S.H., Petinggi Ujungbatu, pada 12 Juli 2016).

${ }^{4}$ Sawan laut adalah semacam boreh sebagai obat untuk orang yang terkena tuah atau diganggu oleh makhluk halus dari laut, yang terdiri dari berbagai empon-empon dan bunga yang dihaluskan dengan menggunakan alat tradisional. Sawan laut ini dapat dibeli di pasar tradisional pada penjual emponempon (Wawancara dengan Iskarimah pada $12 \mathrm{Juli}$ 2016).

${ }^{5}$ Oleh karena itu tidak mengherankan jika di dalam berbagai sesaji yang disiapkan itu, menurut $\mathrm{Ibu} \mathrm{Hj}$. Iskarimah, tidak diperkenankan untuk meninggalkan sayur kunci godhong kelor. Karena ada hubungannya dengan nama Pulau Kelor, yang dahulu digunakan sebagai akhir dari pesta lomban itu (Wawancara dengan Iskarimah, 12 Juli 2016).

${ }^{6}$ Cungkup adalah rumah kecil yang menaungi makam.

${ }^{7}$ Empat pusaka itu adalah dua pedang kayu yang dinamai Gendir Gampang Sari dan Podang Sari, sebuah arca, dan sebuah bedug Dobol.

${ }^{8}$ Danyang adalah makhluk halus yang menguasai suatu wilayah. Dalam hal ini adalah wilayah Desa Tegalsambi.

\section{REFERENSI}

Alamsyah (2012). Dinamika Sosial Ekonomi di Keresidenan Jepara 1830-1900. Disertasi. Universitas Padjadjaran.

Alamsyah dan Siti Maziyah (2008). Inventarisasi Benda Cagar Budaya di Jepara. Jepara: Pemda Jepara.

Atmosudiro, Sumijati (2004). "Khasanah Sumber-daya Arkeologi Indonesia: Peluang dan Kendala Pemanfaatannya”. Pidato Pengukuhan Jabatan Guru Besar. Yogyakarta: Universitas Gadjah Mada.

Bapeda Jepara-LPEB STIENU Jepara (2006). Identifikasi dan Pengembangan Sentra Kawasan Produksi di Kabupaten Jepara Tahun 2006.

Bappeda Jepara (2012). Rancangan Akhir Rencana Pembangunan Jangka Menengah Kabupaten Jepara 2012-2017. Jepara: Bappeda. 
Garraghan, S.J. Gilbert (1957). A Guide to Historical Method. New York: New York University Press.

Gustami, S.P. (2000). Seni Kerajinan Mebel Ukir Jepara: Kajian Estetik Melalui Pendekatan Multi Disiplin. Yogyakarta: PT. Kanisius.

Hayati, Chusnul, dkk. (2007). Ratu Kalinyamat: Biografi Tokoh Wanita Abad XVI dari Jepara. Jepara: Pemda Jepara dan Puslit Sosbud Undip.

Koentjaraningrat. (1989). Metode-Metode Penelitian Masyarakat. Jakarta: Gramedia.

Koentjaraningrat (1990). Pengantar Ilmu Antropologi. Jakarta: PT Rineka Cipta.

Maziyah, Siti, dkk. (2006). Peningkatan Pelayanan Wisata Sejarah di Kudus. Laporan Penelitian LPPM Undip.

Hindia Belanda, 1868. "Het Pada Loemban

Feest te Japara.

Koran Muria, 9 April 2016.

Panitia Penyusun Hari Jadi Jepara (1988).

Sejarah dan Hari Jadi Jepara. Jepara:

Pemerintah Kabupaten Daerah Tingkat II Jepara.

Poesponegoro, Marwati Djoened (1993).

Sejarah Nasional Indonesia III. Jakarta:

Balai Pustaka.

Sholikhin, Muhammad (2010). Ritual dan Tradisi Islam Jawa. Penyunting Lilih Prilian Ari Pranowo. Yogyakarta: Narasi.

Soekmono (1993). Pengantar Sejarah Kebudayaan Indonesia 2, Cet. 9. (Yogyakarta: Penerbit Kanisius)

Sulistyono, Singgih Tri, dkk. (2005). Penulisan

Dan Pengkajian Upacara Tradisional di Kabupaten Jepara. Depdikbud Provinsi Jateng.

Slompret Melayu, 12 dan 17 Agustus 1893. http://id.wikipedia.org/wiki/Industri_kreatif, 19 April 2012 jam 23.00 WIB.

http://www.koranmuria.com/2016/04/09/350

53/hanya-sosok-ratu-kalinyamat-yangmuncul-di-kirab-budaya-hut-jepara.html diunduh tgl 5-8-16.

http://berita.suaramerdeka.com/hut-jepara467-tumpeng-dihidangkan/ diunduh tgl 5-816. http://berita.suaramerdeka.com/perayaan-harijadi-jepara-relatif-sepi/ diunduh tgl 5-8-16. http://ongkorongko. blogspot.co.id/2016/05/ pesta-baratan.htm.

http://ceritaanda.viva.co.id/news/read/427323 -pesta-baratan-di-kota-jepara.

http://budaya-indonesia.org/TradisiBaratan. http://www.murianews.com/2016/05/20/834 $27 /$ pesta-baratan-khas_kalinyamatanjepara-lebih-meriah-tahun-ini.html.

http://ceritaanda.viva.co.id/news/read/427323 -pesta-baratan-di-kota-jepara.

http://ongkorongko.blogspot.co.id/2016/05/p esta-baratan.html.

http://www.murianews.com/2016/05/20/834 $27 /$ pesta-baratan-khas-kalinyamatanjeparalebih-meriah-tahun-ini.html).

https://id.wikipedia.org/wiki/Pesta_Baratan.

\section{DAFTAR INFORMAN}

Wawancara dengan Suhendro, 12 Juli 2016.

Wawancara dengan Agus Tri Raharjo, 12 Juli 2016.

Wawancara dengan Slamet Riyadi, pada 13 Juli 2016.

Wawancara dengan Muhamad Asyari, Agustus 2016.

Wawancara dengan Winahyu Widayati, Agustus 2016.

Wawancara dengan Fredy Santoso, Petinggi Ujungbatu, 12 Juli 2016.

Wawancara dengan Iskarimah, 12 Juli 2016. 